The "Theory of Vision Vindicated" is here for the first time available in a really intelligible form; Fraser unfortunately used a very imperfect version that had been printed by Cowell. This short work of Berkeley is valuable because it effectively corrects the false impression sometimes produced on modern readers of the "New Theory of Vision". That was the first thing Berkeley published; it embodied a strictly technical discussion of the processes of sense perception ; it was a necessary preliminary to his philosophy, but did not require its explicit statement. Had he introduced the novel conceptions and the terminology of his "Principles", to be published in the following year, his first readers would have been confused. Berkeley's care for the difficulties of his contemporaries created difficulties for later readers. These, knowing the views of the "Principles" and finding apparently contrary views in the "New Theory", have often accused Berkeley of inconsistency. Anyone who takes the three works in this volume together will see that there is no inconsistency.

t):

Weacher Forecasting

By Instructor-Comdr. S. W. C. Pack. Pp. $192+8$ plates. (London, New Nyrk and Toronto: Longmans, Green and Co., Idd., 1948.) 25s. net.

TNSTRUCTOR-GONGANDER S. W. C. PACK is

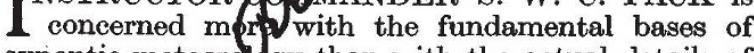
synoptic metegrolgy than with the actual details of weather foredasting. As a grounding, his book is compreher five, beginning with the structure of the atmosp fere and, briefly, meteorological instruments, anfontinuing with a good deal of climatology, which is an essential background to all weather forecasting. Incidentally, the thermometer at Blackadder which recorded a minimum of $-23^{\circ} \mathrm{F}$. was not conventionally exposed. The chapter on "Fronts" and the development of depressions is on the usual lines; but wind in relation to pressure gradient is more clearly demonstrated than is usual in textbooks. The most detailed and best part of the book is the treatment of adiabatic changes, dry and saturated, and the discussion of the tephigram and its uses in determining stability or instability; this should make a difficult subject clear to most students, as should also the later chapter on the variation of wind with height. The chapter on analysis and forecasting covers only eleven pages and is disappointing; there is no actual example of the analysis of a chart, either at ground-level or in the upper air. The book is well illustrated with photographs and clear diagramg but seems high-priced for its size.

\section{A Statlstical Analysis of Advertising Expenditure and of the Revenue the Press}

By Nicholas Kald and Rodney Silverman. (National Institzof of Economic and Social Research, Economic and ocial Studies, 8.) Pp. xiv +200 . Cambridge (At the University Press, 1948.) 15s. net. 7 HIS Cook arose from a proposal made to the 1 If tional Institute by the Advertising Associa. tion (1. an impartial inquiry should be made into the ecpftemic effects of advertising. The authors have carried out a very difficult task with extreme competence and are to be complimented particularly on their method of presentation. The main emphasis has been placed on the period 1934-38, with the result that we now have a comprehensive statistical survey of advertising expenditure in the United Kingdom for the pre-war years. Figures relating to the revenue of the Press extend to more recent years-up to 1944.

This is a most interesting example of what can be achieved when a research body has the full co-operation of professional and trade associations, together with the support of individual firms. Analyses of this nature will be of particular interest to the historian of economics, and it is to be hoped that they will be repeated at regular intervals in the future. The main findings are clearly summarized in the first part of the volume in order to save the time of the less statistically minded reader, and the authors have wisely refrained from detailed comment, leaving the facts to speak for themselves. The second part is devoted to a detailed description of the methods by which the various estimates have been made. Consequently, the book can be strongly recommended to students of economics, not only for its subjectmatter but also for the insight which it gives into methods of approach.

In passing, it is interesting to note how handicapped the investigators were in the absence of a census of distribution. One small criticism is that many references are made to sources of information. While most of these are to be found among the index, it would be helpful to the specialist reader if in a subsequent edition they were to be listed in a bibliography.

Le Bartonien du bassin de Paris

Par L. et J. Morellet. Pp. viii +437 . (Paris : Service de la Carte géologique, 1948.) N.p.

T UCIEN MORIILET, whose death occurred in 1945 , was gue of the many distinguished French geologists of have devoted their attention to the richly fos ilferous Eocene deposits of the Paris Basin. In Cellaboration with his brother, Jean Morellet, he fudied especially the calcareous algæe, on which he w s recognized as a world-wide authority, and the P risian Eocene strata above the Lutetian. The results of more than forty years of observations and collecting by the two workers on this latter subject have now been edited and arranged by M. J. Niorellet, and issued as a memoir of the Service de la Carte Géologique.

This study lists and describes in detail, with copious fossil lists, almost all sections in the Paris Basin 'Etage Bartonien', many of which have been long since obscured, discusses the significance of the fauna and flora with regard to palæogeography and climate, and reviews the history of the classification and correlation of strata at this horizon. In coming to a decision on this vexed question, the authors are wisely tolerant, recognizing the difficulties inherent in the study of these variable strata, and admitting frankly that it is unfortunate that 'Bartonien' was initially proposed for Parisian strata and not for the familiar Barton Beds in England. If it is too much to expect that all students of the Eocene will agree with their 'Bartonien' covering alli Eocene beds above the Lutetian in France, and ranging in England from the base of the Upper Brackleshams to the top of the Lower Headons, the supporting evidence and common-sense nature of the final decision for a single stage are obvious, even if the name retained is unwise.

Meanwhile, the volume is a magnificent detailed record of a type-area invaluable to all students of the older Tertiary, and a fine memorial to the life-work of L. Morellet and the long collaboration between the two brothers; M. J. Morellet is to be congratulated. G. F. E. 